\title{
IDENTIFIKASI MOLEKULER BROAD BEAN WILT VIRUS 2 (BBWV2) DAN CYMBIDIUM MOSAIC VIRUS (CYMMV) ASAL TANAMAN NILAM (POGOSTEMON CABLIN BENTH.)
}

\author{
Miftakhurohmah $^{1}$, Gede Suastika ${ }^{2}$, Tri Asmira Damayanti ${ }^{2}, \&$ Rita Noveriza $^{1}$ \\ ${ }^{1}$ Balai Penelitian Tanaman Rempah dan Obat \\ Jl. Tentara Pelajar No. 3, Bogor 16111 \\ ${ }^{2}$ Departemen Proteksi Tanaman, Fakultas Pertanian, Institut Pertanian Bogor \\ Jl. Kamper, Kampus IPB Dramaga, Bogor 16680 \\ E-mail: miftah_tia05@yahoo.co.id
}

\begin{abstract}
Molecular identification Broad Bean Wilt Virus 2 (BBWV2) and Cymbidium Mosaic Virus (CymMV) from patchouli plant (Pogostemon cablin Benth.). Several viruses have been reported to be associated with mosaic disease on patchouli plant in Indonesia. This study aims to identify the two viruses in patchouli cultivation in West Java by studying the molecular characterization. Mosaic symptomatic leaf samples taken from patchouli cultivation in Manoko (Bandung Barat District, West Java Province). RNA extraction was performed using Xprep Plant RNA mini kit. RNA amplification with RT-PCR technique using primers for the $c p$ gene region of BBWV2 and CymMV. The PCR product was sent to PT. Science Genetics Indonesia to do sequencing, then analyzed nucleotide sequences. Results of RT-PCR were performed successfully obtained DNA bands with size accordance with the predictions of the primer design for BBWV2 and CymMV $c p$ region. Further, based on nucleotide and amino acid sequence analyses, the two virus isolates were confirmed as BBWV2 and CymMV respectively. Phylogenetic analyses revealed that BBWV2 Manoko clustered with BBWV2 from Singapore (original host of Brazilian red-cloak), China (pepper) and South Korea (chili). Whereas, CymMV Manoko become one cluster with CymMV from India (Phaius sp.), Indonesia (Dendrobium), China (vanilla), Thailand (Oncidium), Hawai (Dendrobium) and South Korea (Cymbidium).
\end{abstract}

Key words: nucleotide sequence, virus, patchouli, BBWV2, CymMV

\begin{abstract}
ABSTRAK
Identifikasi molekuler Broad Bean Wilt Virus 2 (BBWV2) dan Cymbidium Mosaic Virus (CymMV)asal tanaman nilam (Pogostemon cablin Benth.). Beberapa virus dilaporkan berasosiasi dengan penyakit mosaik pada tanaman nilam di Indonesia. Penelitian ini bertujuan mengidentifikasi dua virus pada pertanaman nilam di Jawa Barat dengan mempelajari karakterisasi molekulnya. Sampel daun bergejala mosaik diambil dari pertanaman nilam di Manoko (Kabupaten Bandung Barat, Provinsi Jawa Barat). Ekstraksi RNA dilakukan menggunakan Xprep Plant RNA mini kit. Amplifikasi RNA dengan teknik RT-PCR menggunakan primer untuk daerah gen $c p$ BBWV2 dan CymMV. Produk PCR yang dihasilkan dikirimkan ke PT. Genetika Science Indonesia untuk dilakukan perunutan nukleotida, dan selanjutnya dianalisis runutan nukleotidanya. Hasil RT-PCR yang dilakukan berhasil didapatkan pita DNA dengan ukuran sesuai prediksi dari desain primer untuk bagian $c p$ BBWV2 dan CymMV. Berdasarkan analisis runutan nukleotida dan asam amino, dua virus yang ditemukan merupakan BBWV2 dan CymMV. Analisis homologi dan filogenetik menunjukkan bahwa BBWV2 Manoko mengelompok dengan BBWV2 dari Singapura (Brazilian red-cloak), Cina (lada) dan Korea Selatan (cabai). Sedangkan CymMV Manoko berada dalam satu kelompok dengan CymMV dari India (Phaius sp.), Indonesia (Dendrobium), China (vanili), Thailand (Oncidium), Hawai (Dendrobium) dan Korea Selatan (Cymbidium).
\end{abstract}

Kata kunci: sekuen nukleotida, virus, nilam, BBWV2, CymMV

\section{PENDAHULUAN}

Infeksi virus pada tanaman nilam di Indonesia telah ditemukan sejak tahun 1996 oleh Sumardiyono et al. (1996), yang berdasarkan uji serologi dengan antibodi patchouli mottle virus (PatMoV), menunjukkan reaksi positif. Pada pertanaman nilam di Cianjur dan Bogor, ditemukan infeksi campuran antara cucumber mosaic virus (CMV) dan genus Potyvirus (Sukamto et al., 2007). Gejala mosaik ditemukan pada beberapa pertanaman nilam di Jawa Tengah, Jawa Barat, Sumatera Utara dan Sumatera Barat. Berdasarkan hasil 
deteksi dan identifikasi, penyakit berasosiasi dengan telosma mosaic virus (TeMV) yang tergolong ke dalam genus Potyvirus (Noveriza et al., 2012).

Selain genus Potyvirus dan CMV, juga ditemukan infeksi virus lain pada pertanaman nilam di Manoko (Kabupaten Bandung Barat, Provinsi Jawa Barat) yang berdasarkan deteksi secara serologi merupakan BBWV2 dan CymMV. Kedua virus tersebut merupakan virus pada tanaman nilam yang tergolong patogen A1, dalam arti belum pernah ada laporan serangan virus ini pada tanaman di Indonesia (Badan Karantina Pertanian, 2011). Berdasarkan pengamatan, saat ini sebagian besar bibit nilam hasil perbanyakan vegetatif sudah terserang virus dengan berbagai gejala sebelum ditanam di lapangan.

Berdasarkan hal tersebut diatas, perlu dilakukan identifikasi lanjut BBWV2 dan CymMV yang menginfeksi pertanaman nilam. Deteksi secara serologi memiliki kelemahan, yaitu tidak bisa membedakan virus yang sekerabat, terutama bila yang digunakan antiserum universal genus. Selain itu, beberapa antigenic site dimiliki oleh virus yang tidak sekerabat, sehingga memungkinkan terjadinya reaksi silang (Putnam, 1995). Oleh karena itu, hasil deteksi secara serologi perlu dilanjutkan dengan identifikasi berdasarkan asam nukleat. Hasil identifikasi digunakan sebagai salah satu dasar dalam pengambilan tindakan pengendalian.

Identifikasi berdasarkan asam nukleat dilakukan secara molekuler, dengan teknik Polymerase chain reaction (PCR). Untuk diagnosis virus tanaman yang memiliki asam nukleat RNA, RNA target dikonversikan menjadi complementary DNA (cDNA) yang dikopi dengan transkripsi balik sebelum PCR dimulai (Naidu \& Hughes, 2003).

Dari hasil RT-PCR, selanjutnya dilakukan perunutan nukleotidanya, yang dapat digunakan untuk mengklasifikasikan virus berdasarkan genomnya. Penelitian terdahulu menunjukkan bahwa analisis runutan nukleotida coat protein $(c p)$ sangat berguna dalam kegiatan identifikasi BBWV1 dan BBWV2 (Kobayashi et al., 2005; Kondo et al., 2005). Beberapa software telah tersedia untuk mengklasifikasikan virus berdasarkan genomnya, diantaranya BioEdit, MEGA, dan GeneDoc (Tamura et al., 2007; Hall, 1999).

Penelitian bertujuan mengidentifikasi BBWV2 dan CymMV pada tanaman nilam di Jawa Barat dengan mempelajari karakterisasi molekulnya.

\section{METODE PENELITIAN}

Tempat dan Waktu. Penelitian dilaksanakan di Laboratorium Virologi Tumbuhan, Fakultas Pertanian,
Institut Pertanian Bogor, dari bulan Februari sampai dengan Agustus 2012.

Sumber Virus. Virus diambil dari daun bergejala mosaik pada pertanaman nilam di Kebun Percobaan (KP) Manoko (Kabupaten Bandung Barat). Gejala mosaik yang ditemukan bervariasi, dari mosaik lemah, mosaik kuning hijau, mosaik hijau muda hijau tua, mosaik dengan penebalan dan mosaik dengan perubahan bentuk daun (malformasi).

\section{Reverse transcription polymerase chain reaction (RT-PCR)}

Ekstraksi RNA. Ekstraksi RNA dilakukan dengan Xprep Plant RNA mini kit (PKT-Philekorea Technology). Bufer XPRB disiapkan dengan menambahkan $1 \%$ mercaptoethanol (ME). Sampel daun nilam sebanyak $0,1 \mathrm{~g}$ digerus menggunakan nitrogen cair pada mortar, sampai menjadi serbuk. Serbuk sampel ditambah bufer XPRB yang telah ditambah ME, dimasukkan ke dalam kolom filter dan disentrifugasi selama dua menit pada kecepatan $13.000 \mathrm{rpm}$. Supernatan dipindahkan ke tabung eppendorf baru dan etanol absolut ditambahkan sebanyak 0,5 kali volume supernatan, dan dicampur dengan cara dipipet atau dibolak-balik. Kemudian supernatan dalam alkohol dimasukkan ke dalam kolom XPPLR mini, dan disentrifugasi selama satu menit pada kecepatan 13.000 rpm. Setelah supernatan dibuang, kolom diberi wash buffer 1 (WB1) sebanyak $500 \mu 1$, disentrifugasi selama satu menit, dan supernatan dibuang. Wash buffer 2 (WB2) sebanyak $750 \mu \mathrm{l}$ ditambahkan ke dalam kolom, disentrifugasi selama satu menit, dan supernatan dibuang. Selanjutnya, untuk mengeringkan kolom, dilakukan sentrifugasi kolom selama tiga menit pada kecepatan $13.000 \mathrm{rpm}$. RNA total dikoleksi dengan cara memberikan air bebas nuklease sebanyak $50 \mu \mathrm{l}$ ke pusat membran kolom XPPLR yang diletakkan pada tabung eppendorf baru, dibiarkan selama satu menit, lalu disentrifugasi selama satu menit. RNA yang telah diperoleh disimpan di freezer $-80^{\circ} \mathrm{C}$, sampai digunakan.

Sintesis complementary DNA (c-DNA ). Reaksi reverse transcription (RT) dilakukan untuk membuat cDNA dengan menggunakan enzim reverse transcriptase. Pereaksi yang digunakan terdiri atas air bebas nuklease $(3,7 \mu \mathrm{l})$, bufer RT $5 \mathrm{x}(2 \mu \mathrm{l})$, DTT 50 $\mathrm{mM}(0,35 \mu \mathrm{l})$, dNTP $10 \mathrm{mM}(0,5 \mu \mathrm{l})$, M-MuLV Rev (Fermentas) $(0,35 \mu \mathrm{l})$, RNase Inhibitor $(0,35 \mu \mathrm{l})$, Oligo $\mathrm{d}(\mathrm{T}) 10 \mu \mathrm{M}(0,75 \mu \mathrm{l})$ dan RNA templat $(2 \mu \mathrm{l})$ dengan total volume sebanyak $10 \mu$ l. Setiap komponen reaksi dipipet satu persatu, dimasukkan ke dalam tabung 
eppendorf berukuran $0,5 \mu 1$, kemudian dimasukkan ke dalam mesin PCR. Reaksi RT dilakukan selama satu jam pada suhu $42^{\circ} \mathrm{C}$.

Amplifikasi cDNA. Untuk amplifikasi DNA, digunakan sepasang primer degenerate untuk BBWV (Kondo et al., 2005) dan satu pasang primer spesifik CymMV (Lee \& Chang, 2008) dengan urutan nukletotida yang dapat dilihat pada Tabel 1. cDNA yang dihasilkan dari hasil RT, diamplifikasi dengan teknik PCR pada volume $25 \mu$ l yang terdiri atas: air bebas nuklease 9,5 $\mu$ l, PCR mix (Go Green Taq-Promega) 12,5 $\mu$ l, primer forward $10 \mu \mathrm{M}$ dan reverse $10 \mu \mathrm{M}$, masing-masing 1 $\mu 1$ dan DNA templat $1 \mu$ l. Setiap komponen reaksi dipipet satu persatu, dimasukkan ke dalam tabung eppendorf berukuran $0,5 \mu \mathrm{l}$, kemudian dimasukkan dalam mesin PCR. Program PCR diatur berbeda, tergantung pasangan primer yang digunakan (Tabel 2).

Visualisasi DNA. DNA hasil amplifikasi dari PCR diseparasi pada gel agarose $1,5 \%$ yang telah ditambah etidium bromida $(0,5 \mu 1 / 10 \mathrm{ml}$ TBE). Sampel dimasukkan ke dalam sumuran gel agarose, kemudian dielektroforesis pada $50 \mathrm{~V}$ selama 60 menit. Adanya pita DNA pada gel agarose dilihat di bawah transilluminator ultraviolet dan didokumentasi dengan kamera digital.

Analisis Runutan Nukleotida cp BBWV2, CymMV, dan Asam Amino CP BBWV2 dan CymMV

Perunutan Nukleotida. Perunutan nukleotida menggunakan mesin sequencer ABI-Prism 3100-Avant Genetic Analyzer di Laboratorium Research and Development Centre PT. Genetika Science. Indonesia.
Hasil runutan dianalisis menggunakan software Blast (www. NCBI. Nml. Niv.gov) dan software Wu-Blast (www.ebi.ac.uk). Contiq hasil perunutan DNA dilakukan dengan bantuan program Sequenche r4.8 dan software Complementor (www.justbio.com). Selanjutnya, hasil runutan yang sudah diolah, ditranslasi menjadi urutan protein (asam amino), dengan bantuan software Translate (www.expasy.org.tools).

Analisis Identitas Matriks dan Filogenetika. Runutan nukleotida yang diperoleh dibandingkan dengan data runutan nukleotida yang ada di GenBank. Matriks identitas nukleotida dan asam amino diperoleh dengan menggunakan software BioEdit versi 7.0. Selanjutnya, gambar pensejajaran runutan nukleotida didapatkan dengan menggunakan program GeneDoc versi 2.7.000. Pohon filogenetika dikonstruksi dengan menggunakan software MEGA 4.0 (Molecular Evolutionary Genetic Analysis software) (Tamura et al., 2007), dengan metode neighbour-joining menggunakan bootstrap 1000 kali ulangan.

\section{HASIL DAN PEMBAHASAN}

\section{Broad Bean Wilt Virus 2}

RT-PCR. Primer yang digunakan yaitu BBWV25 dan BBWV3487M merupakan primer degenerate untuk mengamplifikasi gen coat protein ( $c p)$ BBWV baik BBWV1 maupun BBWV2, sehingga produk yang dihasilkan merupakan gen $c p$ BBWV. Pasangan primer ini telah berhasil digunakan untuk mengamplifikasi gen cp BBWV2 dari tanaman Chinese yam (Dioscorea opposita Thunb.) di Ojima, Jepang (Kondo et al., 2005).

Tabel 1. Primer-primer yang digunakan untuk deteksi virus mosaik nilam

\begin{tabular}{cllcc}
\hline No & \multicolumn{1}{c}{ Primer } & \multicolumn{1}{c}{ Urutan basa } & Ukuran DNA & \multicolumn{1}{c}{ Referensi } \\
\hline 1 & BBWV25 & 5'-AATGARRTKGTNCTCAAYTA-3' & \multirow{2}{*}{$2000 \mathrm{pb}$} & \multirow{2}{*}{ Kondo et al. (2005) } \\
2 & BBW3487M & 5'-AMAMAGGTCATGGAACCCA-3'. & & \\
3 & CyCP-F1 & 5-ATGGGAGAGYCCACTCCARCYCCAGC-3' & \multirow{2}{*}{$679 \mathrm{pb}$} & Lee \& Chang (2008) \\
4 & CyCP-R1 & 5'-ATCGCTCGAGTTCAGTAGGGGGTGCAGGCA-3' & & \\
\hline
\end{tabular}

Tabel 2. Program PCR untuk setiap primer yang digunakan untuk kegiatan PCR

\begin{tabular}{|c|c|c|c|}
\hline No & Primer & Program PCR & Referensi \\
\hline 1 & BBWV25 & enaturasi awal pada suhu $95^{\circ} \mathrm{C}$ ( 5 menit); 35 siklus: $99^{\circ} \mathrm{C}$ ( 1 menit), & \\
\hline 2 & BBW3487M & $55^{\circ} \mathrm{C}(2$ menit $)$ dan $72^{\circ} \mathrm{C}$ ( 3 menit $)$; diakhiri dengan $72^{\circ} \mathrm{C}$ (5 menit) & Kondo et al. (200 \\
\hline 3 & CyCP-F1 & Denaturasi awal pada suhu $96^{\circ} \mathrm{C}$ (5 menit); 30 siklus: $96^{\circ} \mathrm{C}$ (30 detik), & \\
\hline 4 & CyCP-R1 & $52{ }^{\circ} \mathrm{C}(30$ detik $)$ dan $72^{\circ} \mathrm{C}(30$ detik $)$; diakhiri dengan $72{ }^{\circ} \mathrm{C}$ ( 7 menit $)$ & Lee \& Chang (2008) \\
\hline
\end{tabular}


Produk berukuran 2000 pb (pasang basa), berhasil teramplifikasi dari RNA total yang diekstraksi dari daun nilam asal Manoko (Gambar 1). Ukuran pita DNA yang didapatkan sesuai dengan prediksi desain primer yang digunakan, yang menunjukkan terdeteksinya BBWV2 pada sampel daun nilam asal Manoko. Selanjutnya dilakukan perunutan nukleotida terhadap isolat Manoko yang didapatkan.

Homologi runutan nukleotida scp dan asam amino CP BBWV2. Dari hasil kegiatan PCR untuk mengamplifikasi keseluruhan gen $c p$ BBWV2, didapatkan pita DNA berukuran $2000 \mathrm{pb}$. Pada perunutan nukleotida, pembacaan hanya berhasil dilakukan sampai $591 \mathrm{pb}$ (ditranslasikan menjadi 197 asam amino) yang merupakan gen Small Coat Protein (scp). Analisis homologi dan filogenetika dilakukan menggunakan gen scp. Broad bean wilt virus 2 yang menginfeksi tanaman Yam dibandingkan homologi asam amino bagian LCP dan SCPnya dengan beberapa isolat BBWV2 secara terpisah, dimana homologi asam amino SCP cenderung lebih rendah dibandingkan homologi LCP (Kondo et al., 2005). Penggunaan gen $s c p$ juga dilakukan untuk melihat variasi genetik beberapa isolat BBWV2 dari beberapa negara (Ferrer et al., 2011).

Runutan nukleotida scp dan asam amino SCP isolat BBWV2 Manoko dibandingkan dengan 8 isolat BBWV2 dari beberapa negara, satu isolat patchouli mild mosaic virus (PatMMV) dari Jepang dan sebagai isolat di luar grup, digunakan broad bean wilt virus 1 (BBWV1) (Tabel 3).

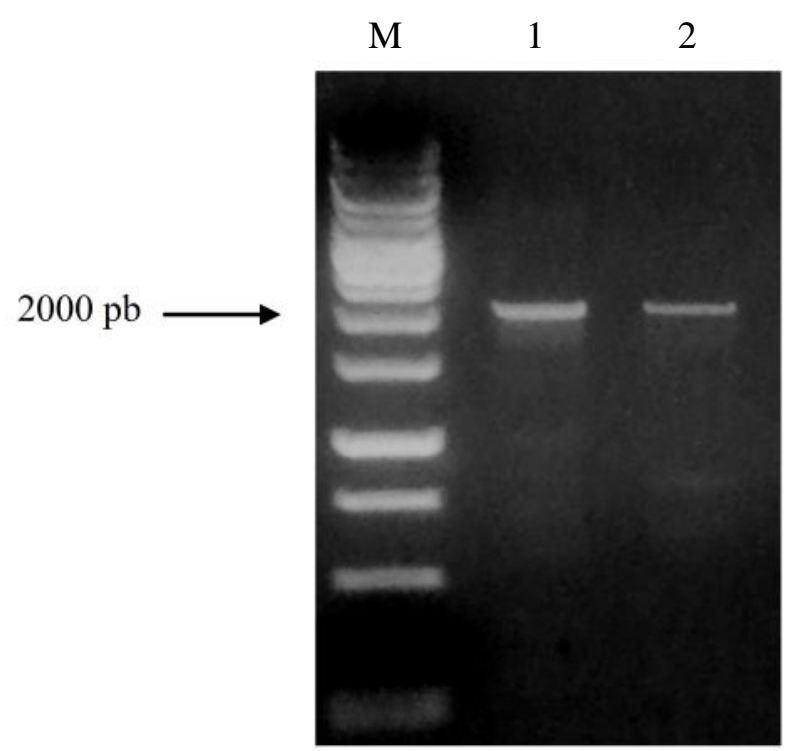

Gambar 1. Hasil visualisasi reverse transcription polymerase chain reaction (RT-PCR) BBWV2 pada gel agarose 1\%. M: Penanda DNA 1 kb plus, 1-2: Isolat Manoko

Tabel 3. Isolat BBWV2, PatMMV dan BBWV1 dari database GenBank yang digunakan untuk membandingkan homologi gen scp BBWV2 Manoko

\begin{tabular}{cllc}
\hline Spesies & Asal isolat & \multicolumn{1}{c}{ Inang/strain } & Kode aksesi \\
\hline \multirow{2}{*}{ BBWV2 } & Cina & Tomat/- & JQ855708 \\
& Jepang & Alstroemeria/ Rs & AB261176 \\
& Taiwan & Salvia dorisiana/Fruit sage & EF392660 \\
& Jepang & Chinese yam/Nagaimo & AB207244 \\
& Singapura & Megakepasma erythrochlamys/ME & AF225954 \\
& Cina & Lada/ XJP1 & HQ283390 \\
& Jepang & Gentiana triflora/- & AB746939 \\
& Korsel & Cabai /RP7 & JX183234 \\
PatMMV_003974 & Jepang & Nilam/- & AY781172 \\
BBWV1 & Spanyol & Cabai/Ben & \\
\hline
\end{tabular}


Hasil analisis homologi runutan nukleotida dan asam amino menunjukkan bahwa gen scp isolat asal Manoko menunjukkan homologi tertinggi sebesar 93,0\% dan 93,9\% dengan BBWV2 asal Singapura. Sedangkan dengan isolat BBWV2 lain dan PatMMV, homologi berdasarkan runutan nukleotida berkisar antara 78,8$90,0 \%$, dan berdasarkan asam amino berkisar antara $88,8-93,4 \%$. Homologi isolat asal Manoko dengan BBWV1, hanya sebesar $63,6 \%$ berdasarkan runutan nukleotida, dan sebesar 58,8\% berdasarkan asam amino (Tabel 4). Hasil ini menunjukkan bahwa virus yang ditemukan merupakan salah satu spesies BBWV2. Dalam genus Fabavirus, virus diklasifikasikan ke dalam spesies yang sama bila homologi gen $c p$ lebih dari $75 \%$ (Fauquet et al., 2005).

Genus Fabavirus nilam di Jepang diidentifikasi sebagai PatMMV. PatMMV memiliki kemiripan morfologi partikel, berat molekul CP dan hubungan serologi dengan isolat BBWV dan lamium mild mosaic virus (LMMV). Namun, PatMMV menunjukkan perbedaan kisaran inang dan gejalanya pada Vicia faba dan Nicotiana tabacum, sehingga digolongkan sebagai spesies baru dalam genus Fabavirus (Natsuaki et al., 1994). Genus Fabavirus yang menginfeksi pertanaman nilam di Indonesia, menunjukkan homologi nukleotida dan asam amino lebih tinggi terhadap BBWV2 asal Singapura, dibandingkan dengan PatMMV. Dengan demikian, genus Fabavirus yang menginfeksi tanaman nilam merupakan BBWV2. Selain itu, PatMMV akhirnya juga diklasifikasikan sebagai salah satu strain BBWV2, karena perbedaan gen $c p$-nya hanya berkisar antara 3-21\% dengan BBWV2 (Fauquet et al., 2005).

BBWV2 memiliki kisaran inang yang luas, menginfeksi tanaman holtikultura dan hias (Ferrer et al.,
2011), namun belum pernah dilaporkan menginfeksi nilam. Secara serologi BBWV2 terdeteksi menginfeksi nilam (Noveriza et al., 2012). Penelitian ini berhasil mengidentifikasi BBWV2 secara molekuler melalui teknik RT-PCR menggunakan primer dengan target gen $c p$ serta analisis runutan nukleotida dan asam aminonya.

Pohon Filogenetika Runutan Nukleotida dan Asam Amino Gen scp BBWV2. Hasil analisis filogenetika berdasarkan runutan nukleotida gen $s c p$ menunjukkan terbentuknya dua kelompok/cluster. BBWV2 Manoko berada dalam satu kelompok dengan BBWV2 Singapura (yang menginfeksi Megakepasma erythroclamys/ME), Cina (lada) dan Korea Selatan (cabai). Isolat PatMMV (nilam) berada pada kelompok lain dengan BBWV2 Taiwan (S. dorisiana), Jepang (Gentiana, yam, Alstroemeria) dan Cina (tomat) (Gambar 2). Hasil analisa filogenetik ini mendukung hasil analisa homologi runutan nukleotida dan asam amino, dimana BBWV2 Manoko memiliki homologi tertinggi dengan BBWV2 Singapura, dan pada pohon filogeni berada dalam satu kelompok.

Hasil analisis filogenetika menunjukkan bahwa pengelompokan isolat-isolat BBWV2 tidak berdasarkan asal isolat. Hal ini terlihat pada kedua isolat Cina, berada pada kelompok yang berbeda. Hasil yang sama juga terjadi pada analisis filogenetika isolat-isolat BBWV2 dari beberapa negara dan dari inang yang berbeda berdasarkan gen $s c p$, terlihat bahwa pengelompokkan tidak berdasarkan inang dan asal isolat (Ferrer et al., 2011).

\section{Cymbidium Mosaic Virus}

RT-PCR. Primer yang digunakan untuk mengamplifikasi gen $c p$ CymMV adalah primer

Tabel 4. Homologi runutan nukleotida dan asam amino gen scp BBWV2 Manoko dengan beberapa anggota genus Fabavirus

\begin{tabular}{|c|c|c|c|c|}
\hline \multirow{2}{*}{ Spesies } & \multirow{2}{*}{ Asal isolat } & \multirow{2}{*}{ Inang/strain } & \multicolumn{2}{|c|}{ Homologi $(\%)$} \\
\hline & & & Nukleotida & Asam amino \\
\hline \multirow{8}{*}{ BBWV2 } & Cina & Tomat/- & 80,5 & 91,3 \\
\hline & Jepang & Alatroemeria/Rs & 78,8 & 88,8 \\
\hline & Taiwan & Salvia dorisiana/Fruit Sage & 80,0 & 88,0 \\
\hline & Singapura & Megakepasma erythroclamys/ME & 93,0 & 94,9 \\
\hline & Cina & Lada/XJP1 & 90,0 & 93,4 \\
\hline & Jepang & Gentiana trifloral- & 80,3 & 89,3 \\
\hline & Korsel & Cabai/RP7 & 88,1 & 92,8 \\
\hline & Jepang & Chinese yam/Nagaimo & 80,7 & 86,8 \\
\hline PatMMV & Jepang & Nilam/- & 79,6 & 89,8 \\
\hline BBWV1 & Spanyol & Cabai/Ben & 63,6 & 58,8 \\
\hline
\end{tabular}


degenerate yang disusun dari 3 genom CymMV (AF016914, AY571289, U62963) yang diambil dari GenBank (Lee \& Chang, 2008). Ketiga genom CymMV tersebut memiliki homologi yang tinggi dengan isolat CymMV asal Manoko berdasarkan analisa BLAST (Miftakhurohmah et al., 2013). Hasil RT-PCR menunjukkan 2 sampel dari Manoko teramplifikasi pita DNA berukuran $679 \mathrm{pb}$, yang berukuran sama dengan kontrol positif (CymMV asal anggrek) (Gambar 3). Hasil ini menunjukkan bahwa dua sampel daun nilam asal Manoko yang dideteksi, positif terinfeksi CymMV.
Selanjutnya, dilakukan perunutan nukleotida terhadap isolat CymMV asal Manoko yang didapatkan.

Homologi Runutan Nukleotida dan Asam Amino Gen $\boldsymbol{c}$ p CymMV. Gen $c p$ CymMV berhasil dirunut berukuran $681 \mathrm{pb}$, yang ditranslasikan menjadi 227 asam amino, dimana hasil translasi menunjukkan $\mathrm{CP}$ penuh. Pensejajaran gen $c p$ CymMV dilakukan dengan membandingkan homologinya dengan 8 isolat CymMV dari beberapa negara, satu isolat CymMV Indonesia, dan sebagai pembanding di luar grup, digunakan satu isolat PVX (Tabel 5).

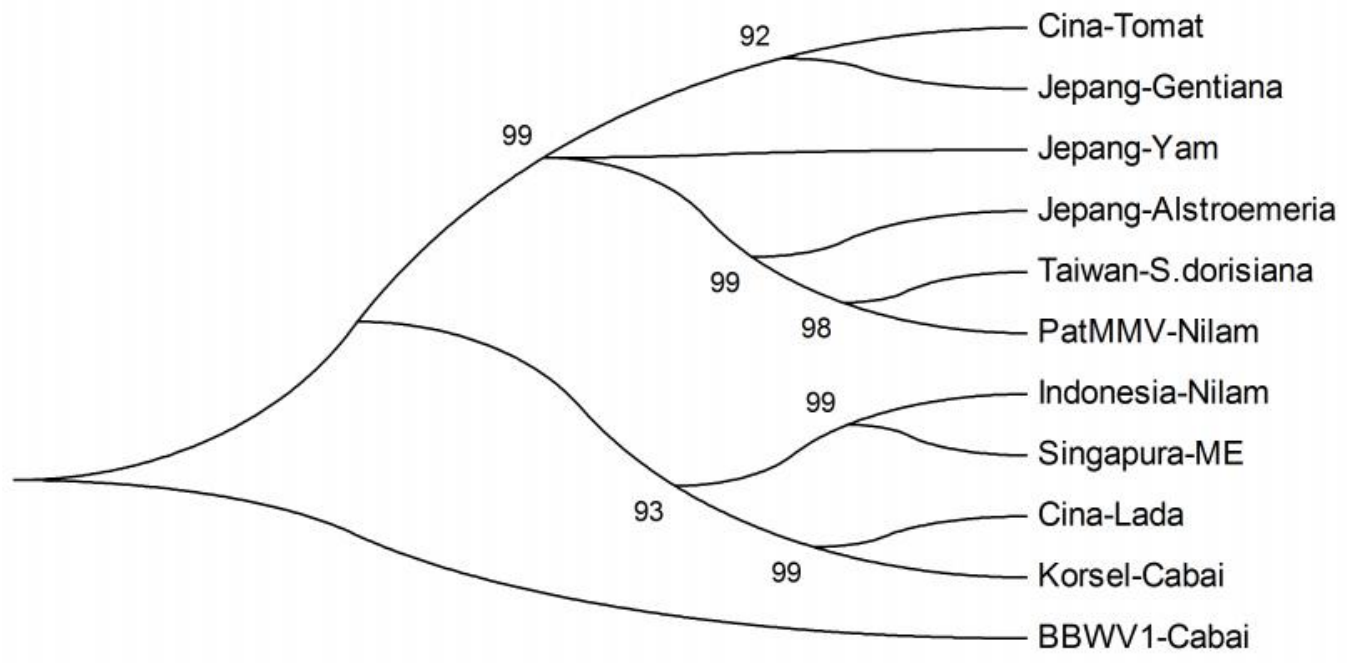

Gambar 2. Pohon filogenetika BBWV2 isolat Manoko berdasarkan runutan nukleotida gen scp. Pohon filogenetika dibuat dengan menggunakan software MEGA 4.0, metode neighbour-joining, dengan bootstrap sebanyak 1000 kali. BBWV1 digunakan sebagai pembanding di luar grup

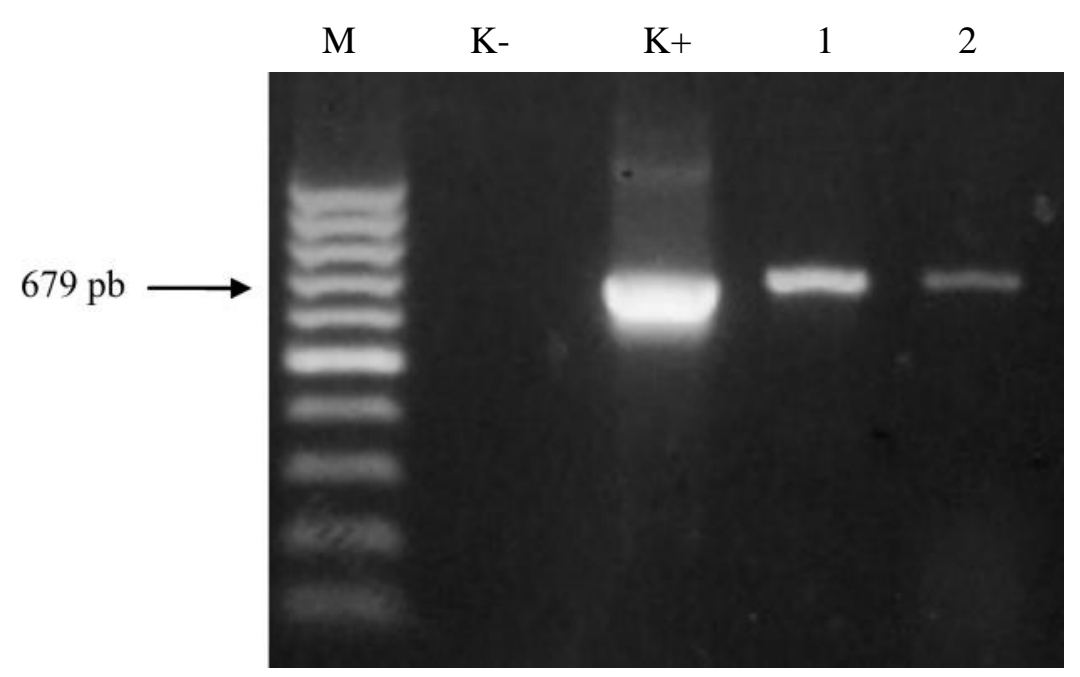

Gambar 3. Hasil visualisasi reverse transcription-polymerase chain reaction (RT-PCR) CymMV pada gel agarose 1,5\%. M: Penanda DNA 100 pb, K-: kontrol negatif, K+: kontrol positif, 1-2: sampel Manoko 
Runutan nukleotida gen $c p$ CymMV isolat Manoko terlihat memiliki kemiripan yang tinggi $(88,5-$ 96,8\%) dengan sembilan isolat CymMV dari beberapa negara. Homologi tertinggi yaitu sebesar 96,8\% dengan isolat CymMV dari Korea Selatan (Cymbidium), dan homologi terendah sebesar 88,5\% dengan isolat CymMV Thailand (Oncydium). CymMV isolat Manoko memiliki homologi sebesar 95,8\% dengan CymMV Indonesia (Dendrobium). Sedangkan dengan PVX sebagai isolat di luar grup, hanya memiliki homologi sebesar $48,6 \%$ (Tabel 6).

Tingkat homologi yang tinggi dengan isolat-isolat CymMV dari negara lain juga didapatkan dari hasil penghitungan homologi runutan asam amino CP CymMV asal Manoko, dengan kisaran antara 94,6-99,1\%. Homologi tertinggi dengan isolat CymMV asal Korea Selatan, sedangkan homologi terendah dengan CymMV Thailand. Sedangkan dengan PVX sebagai isolat di luar grup, seperti halnya isolat-isolat CymMV lain, tingkat kemiripannya rendah, hanya sebesar 35,8\% (Tabel 6).

CymMV Manoko mengalami mutasi nukleotida pada beberapa titik dibandingkan dengan 9 isolat CymMV dari beberapa negara, termasuk CymMV Indonesia asal Dendrobium. Mutasi pada urutan nukleotida ke-10 dan ke-82 menyebabkan perubahan asam amino pada posisi ke-4, yaitu dari proline menjadi serine, dan ke-28, dari alanine menjadi threonine (Gambar 4). Sedangkan mutasi pada titik yang lain tidak menyebabkan perubahan asam amino.

CymMV Manoko memiliki perbedaan nukleotida pada titik ke 670-672, serta tambahan 9 nukleotida di akhir runutan gen $c p$, dibandingkan dengan gen $c p$ CymMV Indonesia dan beberapa CymMV yang lain. Nukleotida TAA yang berada pada posisi 670-672, yang mengkode stop kodon, bergeser posisinya ke titik 679681. Pada titik 670-678, merupakan tambahan 9

Tabel 5. Isolat CymMV dari database GenBank yang digunakan untuk membandingkan homologi gen $c p$ CymMV Manoko

\begin{tabular}{llll}
\hline Spesies & \multicolumn{1}{c}{ Asal Isolat } & \multicolumn{1}{c}{ Inang/Strain } & Kode Aksesi \\
\hline \multirow{2}{*}{ CymMV } & Korea Selatan & Cymbidium/CYK9 & AB541542 \\
& Cina & Vanili/HNXL & HQ681906 \\
& Indonesia & Dendrobium & AB693982 \\
& Hawai & Dendrobium/2 & EF125179 \\
& Thailand & Oncidium/- & AY376393 \\
& Cina & Cymbidium/GD3 & AY360410 \\
& India & Vanili/- & DQ208422 \\
& Singapura & Dendrobium/- & AF405728 \\
& India & Phaius tancarvilleae & AJ564562 \\
PVX & Cina & Terong & AF485891 \\
\hline
\end{tabular}

Tabel 6. Homologi nukleotida dan asam amino gen CP CymMV Manoko dengan beberapa CymMV asal beberapa negara

\begin{tabular}{|c|c|c|c|c|}
\hline \multirow{2}{*}{ Spesies } & \multirow{2}{*}{ Negara } & \multirow{2}{*}{ Inang/Strain } & \multicolumn{2}{|c|}{ Homologi (\%) } \\
\hline & & & Nukleotida & Asam Amino \\
\hline \multirow[t]{9}{*}{ CymMV } & Cina & Cymbidium/GD3 & 96,1 & 98,2 \\
\hline & Korea Selatan & Cymbidium/CYK9 & 96,8 & 99,1 \\
\hline & India & Phaius tancarvilleae & 95,5 & 96,4 \\
\hline & Cina & Vanili/HNXL & 95,8 & 98,6 \\
\hline & Indonesia & Dendrobium/- & 95,8 & 97,7 \\
\hline & India & Vanili/- & 95,3 & 97,3 \\
\hline & Thailand & Oncidium/- & 88,5 & 94,6 \\
\hline & Hawai & Dendrobium/2 & 89,4 & 97,7 \\
\hline & Singapura & Dendrobium/- & 94,7 & 96,8 \\
\hline PVX & Cina & Terong & 48,6 & 35,8 \\
\hline
\end{tabular}


nukleotida, yang ditranslasikan menjadi asam amino leucine, glutamic acid dan arginine (Gambar 5).

Perubahan dan tambahan beberapa asam amino CP CymMV Manoko ini diduga mempengaruhi perbedaan inang CymMV Manoko dan isolat CymMV lain. CymMV dilaporkan hanya menginfeksi tanaman dalam famili Orchidaceae, sedangkan CymMV Manoko menginfeksi tanaman nilam yang tergolong ke dalam famili Lamiaceae. Hal ini terjadi karena gen $c p$ genus Potexvirus selain berperan sebagai pembentuk selubung protein, juga berperan dalam pergerakan virus antar sel (sebagai tambahan), yang mempengaruhi penyebaran virus (Scholthof, 2005). Gen $c p$ CymMV M1 berperan penting dalam perpindahan sel ke sel. Perbedaan empat asam amino pada $\mathrm{CP}$ dua strain CymMV asal anggrek menyebabkan CymMV M1 mampu berpindah ke seluruh bagian tanaman tembakau (Nicotiana tabacum) yang menyebabkan gejala sistemik, sedangkan CymMV M2 hanya menyebabkan gejala lokal (Lu et al., 2009).

Genus Potexvirus pada nilam di Brazil diidentifikasi sebagai virus baru, yang dinamakan dengan PatVX (Filho et al., 2002). Namun demikian, peneliti dari Brazil tersebut hanya melakukan pembuatan antiserum, uji serologi baik dengan antiserum dan dengan uji protein, tanpa melakukan sekuensing. Dengan demikian, runutan nukleotida dan asam amino isolat CymMV yang didapatkan dari nilam tidak bisa dibandingkan homologinya dengan genom PatVX yang ditemukan di Brazil.


Gambar 4. Hasil alignment asam amino antara genom CymMV isolat Manoko dengan nukleotida genom- genom CymMV yang didapatkan dari database GeneBank; keterangan: latar belakang warna hitam menunjukkan kesamaan runutan nukleotida antar isolat, sedangkan warna abu-abu menunjukkan ketidaksamaan. Pensejajaran dilakukan dengan program Bioedit. dilanjutkan dengan program GeneDog Ver. 2.7.000 (www.psc.edu/biomed/genedoc) 

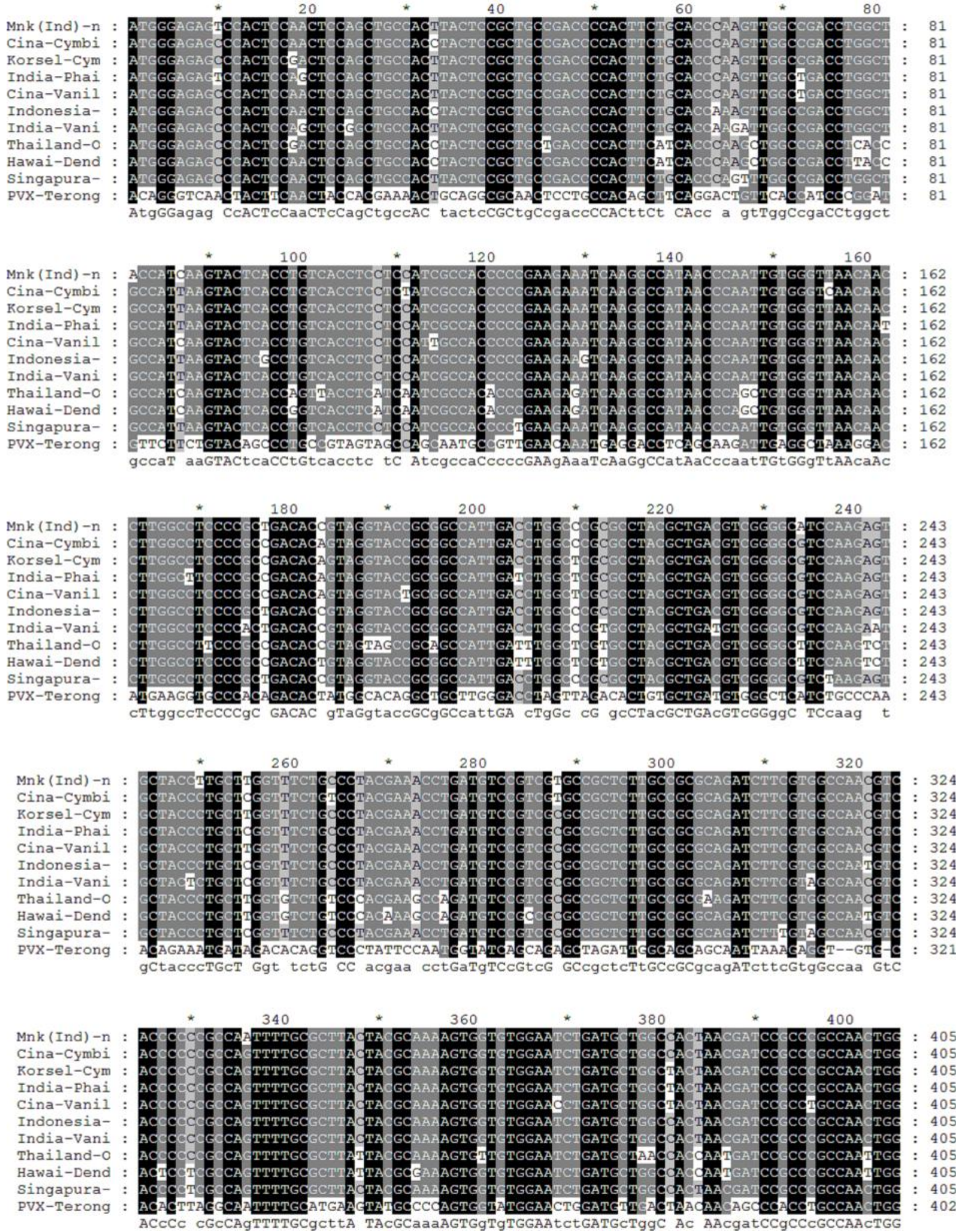

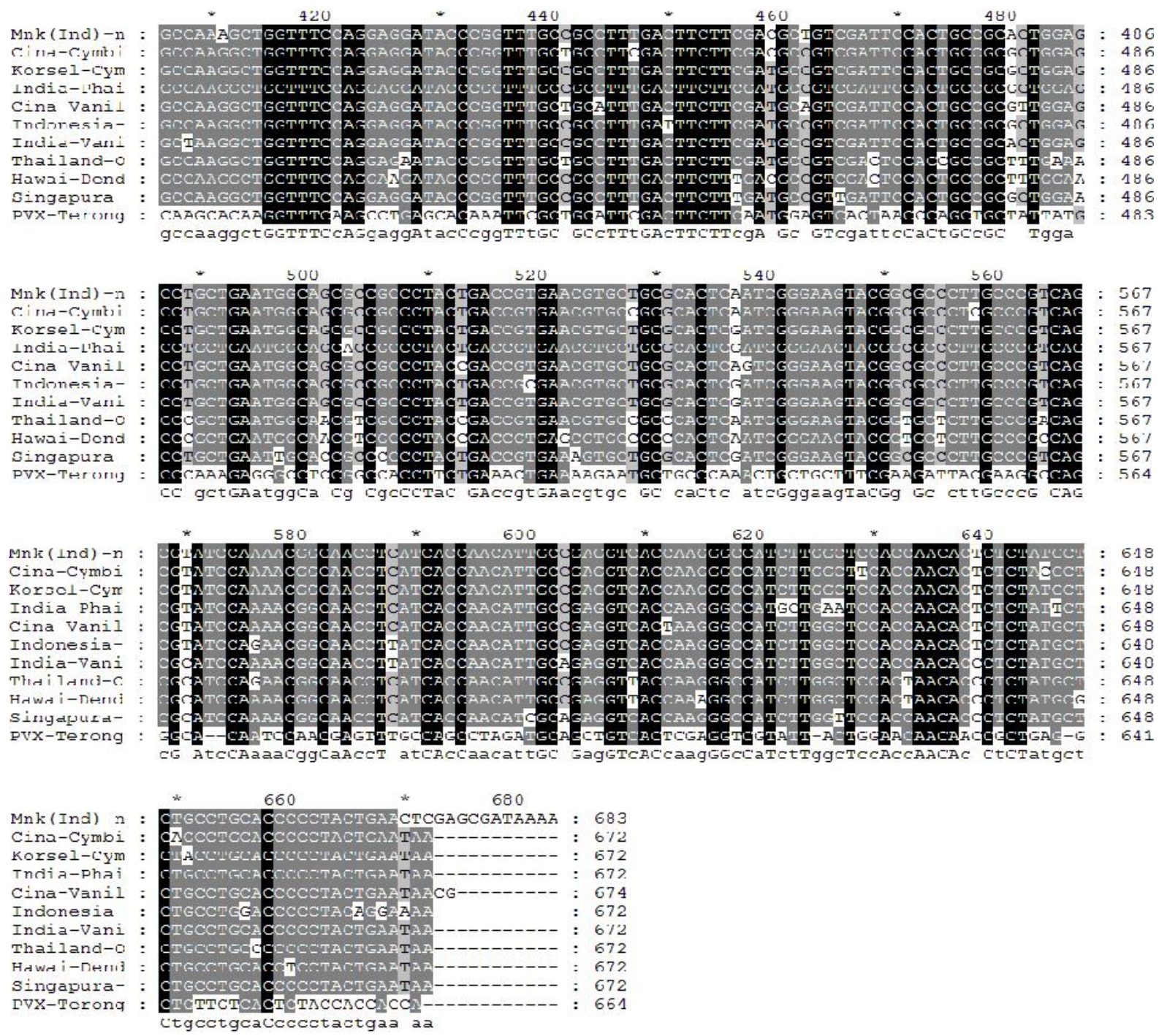

Gambar 5. Hasil alignment nukleotida antara genom CymMV isolat Manoko dengan nukleotida genom-genom CymMV yang didapatkan dari database GeneBank; keterangan: latar belakang warna hitam menunjukkan kesamaan runutan nukleotida antar isolat, sedangkan warna abu-abu menunjukkan ketidaksamaan. Pensejajaran dilakukan dengan program Bioedit. dilanjutkan dengan program GeneDog Ver. 2.7.000 (www.psc.edu/biomed/genedoc)

CymMV telah dilaporkan menginfeksi tanaman anggrek di beberapa negara. Selain tanaman anggrek, CymMV juga dilaporkan menginfeksi tanaman vanili (Grisoni et al., 2004). Di Indonesia, CymMV telah dilaporkan menginfeksi tanaman anggrek (Lakani et al., 2010). Namun demikian, infeksi CymMV pada tanaman nilam belum pernah dilaporkan. Dengan demikian, penelitian ini merupakan laporan pertama infeksi CymMV pada tanaman nilam.

Pohon Filogenetika Runutan Nukleotida $c p$ dan Asam Amino CP CymMV. Hasil analisis filogenetika runutan nukleotida gen $c p$ membentuk 2 kelompok/ cluster. Isolat Manoko berada dalam satu kelompok dengan CymMV Indonesia (Dendrobium), Cina (Cymbidium), Korea Selatan (Cymbidium), India (Phaius sp.), Thailand (Oncidium) dan Hawai (Dendrobium). Isolat Singapura (Dendrobium) dan India (vanili) membentuk kelompok terpisah (Gambar $6)$.

Hasil analisa homologi asam amino dan nukleotida serta filogenetik menunjukkan bahwa isolat Manoko yang ditemukan merupakan CymMV. Virus diklasifikasikan ke dalam spesies yang sama bila gennya memiliki homologi nukleotida lebih dari $72 \%$ atau asam amino lebih dari 80\% (Fauquet et al., 2005). 


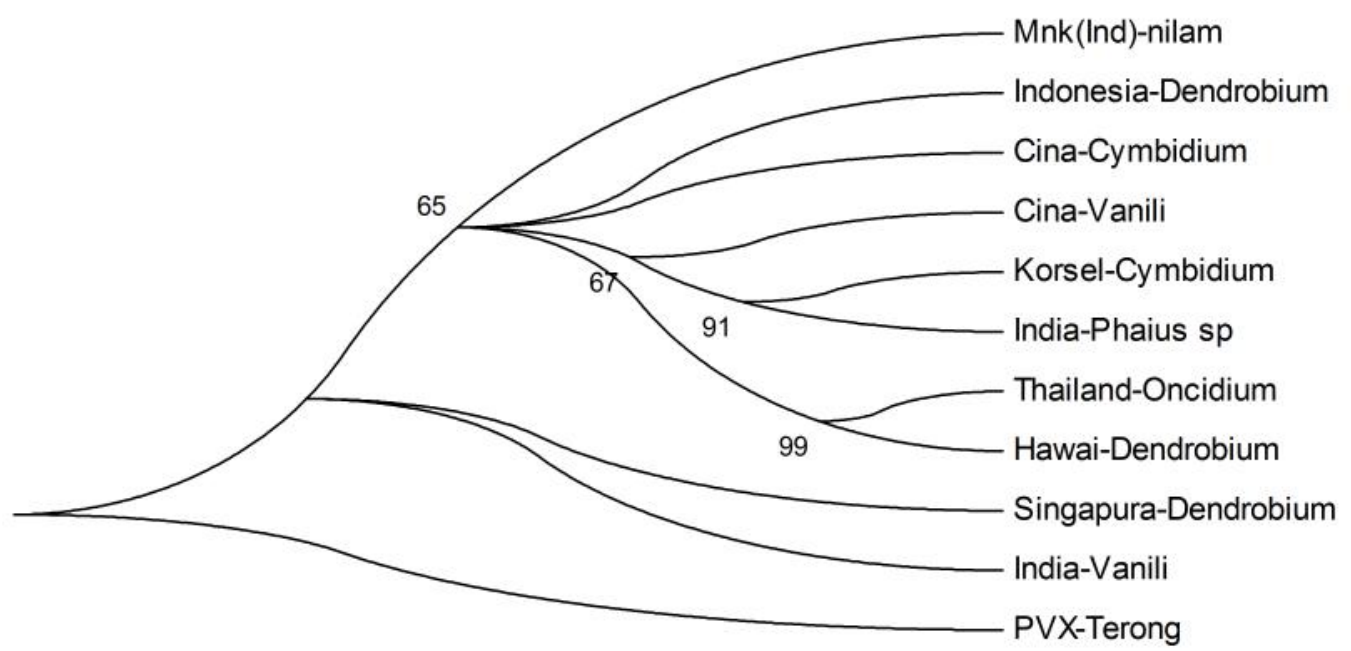

Gambar 6. Pohon filogenetika CymMV isolat Manoko (Lembang) berdasarkan runutan nukleotida gen $c p$. Pohon filogenetika dibuat menggunakan software MEGA 4.0, metode neighbour-joining, dengan bootstrap sebanyak 1000 kali. PVX digunakan sebagai pembanding di luar grup

\section{SIMPULAN}

Virus yang berasosiasi dengan gejala mosaik pada tanaman nilam adalah BBWV2 dan CymMV. Hasil analisis homologi dan pohon filogenetika menunjukkan bahwa BBWV2 asal Manoko mengelompok dengan BBWV2 dari Singapura asal tanaman hias Megakepasma erythroclamys/ME), Cina asal tanaman lada dan Korea Selatan asal tanaman cabai. Sedangkan CymMV asal Manoko berada dalam satu kelompok dengan CymMV dari Indonesia, Cina, Korea Selatan, India, Thailand, dan Hawai yang berasal dari beberapa jenis anggrek. Isolat CymMV yang ditemukan merupakan laporan pertama teridentifikasi pada nilam di Indonesia.

\section{SANWACANA}

Penulis mengucapkan terima kasih kepada Dr. Irwan Lakani yang telah membantu kegiatan analisis runutan nukleotida gen $c p$ BBWV2 dan CymMV serta asam amino CP BBWV2 dan CymMV.

\section{DAFTAR PUSTAKA}

\author{
Badan Karantina Pertanian. 2011. Basis Data \\ Organisme Pengganggu Tumbuhan \\ Karantina. Badan Karantina Pertanian. \\ Departemen Pertanian Republik Indonesia. \\ http://karantina.deptan.go.id/optk/index.php. \\ Diakses tanggal 14 April 2011.
}

Fauquet CM, Mayo MA, Maniloff J, Desselberger U, \& Ball LA. 2005. Virus Taxonomy. Classification and Nomenclature of Viruses. Elsevier Academic Press. New York.

Ferrer RM, Ferrior I, Moreno P, Guerri J, \& Rubio L. 2011. Genetic variation and evolutionary analysis of Broad bean wilt virus 2. Arch. Virol. 156(8): 1445-1450.

Filho PEM, Resende RO, Lima MI, \& Kitajima EW. 2002. Pantchouli virus $\mathrm{x}$, a new potexvirus from Pogostemon clabin. Annu. Appl. Biol. 141:267274.

Grisoni M, Davidson F, Hyrondelle C, Farreyrol K, Caruana ML, \& Pearson M. 2004. Nature, incidence and symptomatology of viruses infecting Vanilla tahitensis in French Polysenia. Plant Dis. 88(2): 119-124.

Hall TA. 1999. BioEdit: a user-friendly biological sequence alignment editor and analysis program for Windows 95/98/NT. Nucleic Acid Symp. Ser. 41: 95-98.

Kondo T, Fuji S, Yamashita K, Kang DK, \& Chang MU. 2005. Broad bean wilt virus 2 in yams. J. Gen. Plant Pathol. 71: 441-443.

Kobayashi YO, Kobayashi A, Hagiwara K, Uga H, Mikoshiba Y, Naito T, Honda Y, \& Omura T. 2005. Gentian mosaic virus: a new spesies in the genus Fabavirus. Phytopathology 95(2): 192-197. 
Lakani I, Suastika G, Mattjik N, \& Damayanti TA. 2010. Identification and molecular characterization of Odontoglossum ringspot virus (ORSV) from Bogor, Indonesia. Hayati J. Biosci. 17(2): 101104.

Lee SC \& Chang YC. 2008. Performances and application of antisera produced by recombinant capsid proteins of Cymbidium mosaic virus and Odontoglossum ringspot virus. Eur. J. Plant Pathol. 122: 297-306.

Lu HC, Chen CE, Tsai MH, Wang H, Su HJ, \& Yeh HH. 2009. Cymbidium mosaic potexvirus isolate-dependent host movement systems reveal two movement control determinants and the coat protein is the dominant. Virology 388(1): 147159.

Miftakhurohmah, Suastika G, \& Damayanti TA. 2013. Deteksi secara serologi dan PCR beberapa jenis virus yang berasosiasi dengan penyakit mosaik pada tanaman nilam (Pogostemon cablin Benth). J. Littri. 19(3): 130-138.

Naidu RA \& Hughes JDA. 2003. Methods for the detection of plant viral diseases of plant viral diseases in plant virology in sub-Saharan Africa. Proceedings of Plant Virology. pp. 233-260. Nigeria. http://old.iita.org/cms/details/virology/ pdf_files /233-260.pdf. Accessed on 2011 June 16.

Natsuaki KT, Tomaru K, Ushiku S, Ichikawa Y, Sugimura Y, Natsuaki T, Okuda S, \& Teranaka M. 1994. Characterization of two viruses isolated from patchouli in Japan. Plant Dis. 78(1): 1094 1097.
Noveriza R, Suastika G, Hidayat SH, \& Kartosuwondo U. 2012. Potyvirus associated with mosaic disease on patchouli (Pogostemon cablin (Blanco) Benth.) plants in Indonesia. J. ISSAAS. 18(1): 131-146.

Putnam ML. 1995. Evaluation of selected methods of plant diagnosis. Crop Prot. 14(6): 517-525.

Scholthof HB. 2005. Plant virus transport: motions of functional equivalence. Trends Plant Sci. 10(8): 376-382.

Sukamto, Rahardjo IB, \& Sulyo Y. 2007. Detection of Potyvirus on patchouli plant (Pogostemon cablin BENTH) from Indonesia. Proceeding of International Seminar on Essential Oil. pp. 72 77. Jakarta. 7-9 November 2007.

Sumardiyono YB, Sulandari S, \& Hartono S. 1996. Penyakit mosaik kuning pada nilam (Pogostemon cablin). Risalah Konggres Nasional XII dan Seminar Ilmiah Perhimpunan Fitopatologi Indonesia. pp. 912-916. Yogyakarta. 6-8 September 1996.

Tamura K, Dudley J, Nei M, \& Kumar S. 2007. MEGA 4: molecular evolutionary genetic analysis (MEGA) software version 4.0. Mol. Biol. Evol. 24(8): $1596-1599$. 